by minor functional visual disabilities which are absent in younger individuals. Therefore, in considering the effects of aging on vision, it is important to differentiate between reduced visual function in the normal healthy elderly individual and the elderly patient with specific age related disease. While the latter group deserve special research effort to be directed towards them, the former group's possible reduced quality of life also needs to be addressed.

J V FORRESTER

\section{Editor, BJO}

1 Muller DC, Elahi D, Tobin JD,Andres R. The effect of age on insulin resistance and secretion: a review. Nephrology 1997;16:289-98.

. The Rosenberg T, Klie F. The incidence of registered blindness caused by ge-related macular degeneration. Acta Ophthalmol Scand 1996;74:399402 .

4 Rahmani B, Tielsch JM, Katz J, Gottsch J, Quigley H, Javitt J, et al. The cause-specific prevalence of visual impairment in an urban population. Ophthalmology 1996;103:1721-6.

5 World Health Organisation. Strategies for the prevention of blindness in national programmes. Geneva: WHO, 1997:68.

6 Limburg H, Kumar R, Bachani D. Monitoring and evaluating cataract intervention in India. Br f Ophthalmol 1996;80:951-5.
7 Quigley HA, Vitale S. Models of open-angle glaucoma prevalence and incidence in the United States. Invest Ophthalmol Vis Sci 1997;38:83-91.

8 Zhang K, Nguyen TH, Crandall A, Donoso LA. Genetic and molecular studies of macular dystrophies: recent developments. Surv Ophthalmol studies of macula

9 Belmouden A, Adam MF, Dupont de Dinechin S, Brezin AP, Rigault P, Chumakov I, et al. Recombinational and physical mapping of the locus for primary open-angle glaucoma (GLC1A) on chromosome 1q23-q25. Genomics 1997;39:348-58.

10 Nyakas C, Buwalda B, Luiten PG. Hypoxia and brain development. Prog Neurobiol 1996;49:1-51.

11 Taylor A, Jacques PF, Epstein EM. Relations among aging, antioxidant status, and cataract. Am f Clin Nutr 1995;62(6S):1439S-47S.

12 de Grey $\mathrm{AD}$. A proposed refinement of the mitochondrial free radical theory. Bioessays 1997;19:161-6.

13 Booth AA, Khalifah RG, Todd P, Hudson BG. In vitro kinetic studies of formation of antigenic advanced glycation end products (AGEs). Novel inhi-

14 Liu AY, Lee YK, Manalo D, Huang LE. Attenuated heat shock transcriptional response in aging: molecular mechanism and implications in the biology of aging. EXS 1996;77:393-408.

15 Davies KJ. Oxidative stress: the paradox of the aerobic life. Biochem Soc Symp 1995;61:1-31.

16 Taylor HR, Livingston PM, Stanislavsky YL, McCarty CA. Visual impairment in Australia: distance visual acuity, near vision, and visual field findings of the Melbourne Visual Impairment Project. Am f Ophthalmol 1997;123:328-37.

17 Paige GD. Senescence of the human visual-vestibular interactions: smooth pursuit, optokinetic and vestibular control of eye movements with aging. Exp Brain Res 1994;98:355-72.

\title{
Aging and the pathogenesis of retinal vein thrombosis
}

Venous thrombosis has a 'multiple hit' pathogenesis in which several adverse influences affecting the composition of the blood, the structure and function of the vessel wall, and blood flow together result in an acute thrombotic event. ${ }^{1}$ This is exemplified by the long recognised clinical factors which predispose to thrombosis in the deep veins of the limbs. For example, the coagulation activation associated with surgical trauma combines with stasis of venous flow due to postoperative immobility to result in a high risk of venous thromboembolism (VTE) after major surgical procedures.

Other clinical risk factors for VTE include obesity, pregnancy, and use of the combined oral contraceptive or hormone replacement preparations. A range of diseases also predispose to VTE, especially malignancy, including myeloproliferative disorders, and less common conditions such as paroxysmal nocturnal haemoglobinuria and Behçet's disease. Among the biochemical and haemostatic variables which have been associated with VTE there has been considerable recent interest in hyperhomocysteinaemia, especially as this is partly determined by diet and it also predisposes to arterial occlusive events. Other notable associations with VTE are a raised plasma concentration of coagulation factor VIII and the antiphospholipid syndromes, where laboratory evidence of lupus anticoagulant and/or anticardiolipin is accompanied by arterial or venous thrombosis.

Over recent years our knowledge of inherited predisposition to VTE has expanded. Hereditary deficiencies of the anticoagulant proteins antithrombin, protein $\mathrm{C}$, and protein $\mathrm{S}$ are rare disorders which are associated with a substantial incidence of VTE, often presenting in young adults and provoked by additional stimuli such as oestrogen use. In activated protein $\mathrm{C}$ resistance (APCR) there is a reduction of the efficiency of the inhibition of activated coagulation factor $\mathrm{V}$ by activated protein $\mathrm{C}$ resulting in a prothrombotic state. Other than during pregnancy, when APCR is a physiological response, this phenomenon is principally due to a mutation present at polymorphic frequency in the gene for factor $\mathrm{V}\left(\mathrm{FV}: \mathrm{Q}^{506}\right)$ which has been given the title factor $\mathrm{V}$ Leiden. The prevalence is high, the heterozygous state being present in around $3-5 \%$ in most European populations and up to $12 \%$ in some.

Age is also a major influence on the prevalence of VTE. There is a fourfold higher rate of limb venous thrombosis per capita among middle aged subjects (age 40-54 years) than young adults (15-24 years). ${ }^{2}$ The elderly are at even higher risk. The mechanisms responsible for this are unclear but aging may introduce alterations to the composition of the blood or to the vessel wall which are prothrombotic.

Retinal venous occlusion (RVO) is a venous thrombotic disorder which also afflicts older subjects, $51 \%$ of cases occurring at more than 65 years of age. ${ }^{3}$ The incidence in 70-79 year olds is threefold higher than that in those aged 50-59 years. ${ }^{4}$ Undoubted associations exist with other conditions, especially hypertension, diabetes mellitus, sedentary lifestyle, and open angle glaucoma, each of which is also age related. ${ }^{5}$

Many of the acquired and inherited risk factors and conditions associated with limb deep venous thrombosis have been sought in subjects with RVO. Occasional cases in which there is deficiency of protein $\mathrm{C}$, protein $\mathrm{S}$, or antithrombin have been reported, ${ }^{67}$ and others with antiphospholipid antibody, ${ }^{8-10}$ myeloproliferative disease, ${ }^{11}$ or hyperhomocysteinaemia. ${ }^{12}$ The most persuasive evidence has been for a relation between RVO and altered blood rheology, ${ }^{13-16}$ especially raised haematocrit and high plasma viscosity.

Recently Larsson et al reported a high prevalence of APCR in patients under 50 years of age who had suffered central retinal vein occlusion (CRVO). ${ }^{17}$ No confirmatory test for factor $\mathrm{V}$ Leiden was performed. While this finding is consistent with the observation that a hypercoagulable state, with increased thrombin generation in vivo, is a feature of RVO, ${ }^{18}$ other investigators have found no, or a much weaker, association between the occurrence of RVO and 
APCR or factor V Leiden. ${ }^{7}{ }^{16-22}$ Larsson and colleagues imply that this discrepancy is at least partly due to the age distribution of the patients under study as, in the current issue of the $B f O(\mathrm{p} 832$ ), they report no excess of APCR in subjects over 50 years of age with CRVO. How do these age related findings fit with the multiple hit pathogenesis of venous thrombosis?

With age there is an increased likelihood of the accumulation of several adverse influences which lead to an increased thrombotic risk. Thus, an individual prothrombotic state, albeit one which is highly prevalent such as factor V Leiden, would make a relatively smaller contribution to the pathogenesis of RVO in an older population, especially as very many of those who carry the gene never suffer a venous thrombotic event.

The same considerations relating to the pathogenesis of VTE dictate that even in those patients with RVO who are found to have APCR and factor V Leiden, the genetic predisposition is unlikely to wholly explain the occurrence. It remains to be determined which other prothrombotic influences are operative. Interactions with other risk factors such as antiphospholipid antibodies, rheological disturbances, and hyperhomocysteinaemia are likely candidates worthy of further investigation. It is noteworthy that antiphospholipid antibody is a common finding in benign intracranial hypertension, another condition in which there is a probable venous thrombotic pathogenesis. ${ }^{23}$ Anatomical factors could also have a role, at least in relation to the site of thrombotic occlusion, as retinal arteriovenous crossings at which the artery lies anterior are associated with RVO. ${ }^{24}$ This anatomical arrangement appears to lead to an abrupt directional change in the vessel, ${ }^{25}$ introducing the potential for local stasis.

In conclusion, venous thrombosis is a multiple hit condition with a multifactorial pathogenesis. This applies also to RVO, for which there is no single identifiable 'cause'. Many of the predisposing factors are age related, and it is this that accounts for the population distribution of the disorder.

MIKE GREAVES

University of Aberdeen Medical School, Foresterhill, Aberdeen AB25 2ZD 1 Greaves M, Taberner DA. Thrombotic disease. In: Weatherall DJ, Ledingham JGG, Warrell DA, eds. Oxford textb
Oxford Medical Publications, 1996;3:3661-76.

2 Rosendaal F. Thrombosis in the young: epidemiology and risk factors, a focus on venous thrombosis. Thromb Haemost 1997;78:1-6.
3 Hayreh SS, Zimmerman MB, Podhajsky P. Incidence of various types of retinal vein occlusion and their recurrence and demographic characterisretinal vein occlusion and their recurrence
tics. Am f Ophthalmol 1994;117:429-41.

tics. Am f Ophthalmol 1994;117:429-41.
4 Mitchell P, Smith W, Chang A. Prevalence and associations of retinal vein occlusion in Australia. The Blue Mountains Eye Study. Arch Ophthalmol 1996;114:1243-7.

5 Anonymous. Risk factors for central retinal vein occlusion. Arch Ophthalmol 1996;114:545-54.

6 Bertram B, Remky A, Arend O, Wolf S, Reim M. Protein C, protein S, and antithrombin III in acute ocular occlusive diseases. Ger f Ophthalmol 1995; 4:332-5.

7 Scat Y, Morin Y, Morel C, Haut J. Occlusion veineuse de la retine et resistance a la proteine C activee. $\mathcal{F}$ Fr Ophtalmol 1995;18:758-62.

8 Bertram B, Haase G, Remky A, Reim M. Anticardiolipin antibodies in vascular occlusion of the eye. Ophthalmologe 1994;91:768-71.

9 Coniglio M, Platania A, Di Nucci GD, Arcieri P, Modzrewska R, Mariani G. Antiphospholipid-protein antibodies are not an uncommon feature in retinal venous occlusions. Thromb Res 1996;83:183-8.

10 Lureau MA, Glacet-Bernard A, Coscas G. Bilateral central retinal vein occlusion and circulating anticoagulant. F Fr Ophtalmol 1995;18:468-72.

11 Yoshizumi MO, Townsend-Pico W. Essential thrombocythemia and central retinal vein occlusion with neovascular glaucoma. Am $\mathcal{f}$ Ophthalmol 1996;121:728-30.

12 Wenzler EM, Rademakers AJ, Boers GH, Cruysberg JR, Webers CA, Deutman AF. Hyperhomocysteinemia in retinal artery and retinal vein occlusion. Am f Ophthalmol 1993;115:162-7.

13 Arend O, Remky A, Jung F, Kiesewetter H, Reim M, Wolf S. Role of rheologic factors in patients with acute central retinal vein occlusion. Ophthalmology 1996;103:80-6.

14 Glacet-Bernard A, Chabanel A, Lelong F, Samama MM, Coscas G. Elevated erythrocyte aggregation in patients with central retinal vein occlusion and without conventional risk factors. Ophthalmology 1994;101:1483-7.

15 Remky A, Arend O, Jung F, Kiesewetter H, Reim M, Wolf S. Haemorheology in patients with branch retinal vein occlusion with and without risk factors. Graefes Arch Clin Exp Ophthalmol 1996;234(Suppl 1):S8-12.

16 Williamson TH, Rumley A, Lowe GD. Blood viscosity, coagulation, and activated protein $C$ resistance in central retinal vein occlusion:a population controlled study. Br f Ophthalmol 1996;80:203-8.

17 Larsson J, Olafsdottir E, Bauer B. Activated protein C resistance in young adults with central retinal vein occlusion. Br f Ophthalmol 1996;80:200-2.

18 Bandello F, Vigano D'Angelo S, Parlavecchia M, Tavola A, Della Valle P, Brancato R, et al. Hypercoagulability and high lipoprotein(a) levels in patients with central retinal vein occlusion. Thromb Haemost 1994;72:3943.

19 Graham SL, Goldberg I, Murray B, Beaumont P, Chong BH. Activated protein $\mathrm{C}$ resistance-low incidence in glaucomatous optic disc haemorrhage and central retinal vein occlusion. Aust NZ $f$ Ophthalmol 1996;24:199-205.

20 Hodgkins PR, Perry DJ, Sawcer SJ, Keast-Butler J. Factor V and antithrombin gene mutations in patients with idiopathic central retinal vein occlusion. Eye 1995;9:760-2.

21 Linna T, Ylikorkala A, Kontula K, Puska P, Tervo T. Prevalence of factor V Leiden in young adults with retinal vein occlusion. Thromb Haemost 1997; 77:212-6.

22 Raguenes O, Mercier B, Escoffre M, Traore L, Blouch MT, Robinet A, et al. $1691 \mathrm{G}$ to A mutation of the factor $\mathrm{V}$ gene: no association with thrombosis of the central retinal vein. Presse Med 1996;25:460.

23 Sussman J, Leach M, Greaves M, Malia R, Davies-Jones GAB. Potentially prothrombotic abnormalities of coagulation in benign intracranial hypertension. F Neurol Neurosurg Psychiatry 1997;62:229-33.

24 Zhao J, Sastry SM, Sperduto RD, Chew EY, Remaley NA. Arteriovenous crossing patterns in branch retinal vein occlusion. The Eye Disease Case-Control Study Group. Ophthalmology 1993;100:423-8.

25 Jefferies P, Clemett R, Day T. An anatomical study of retinal arteriovenous crossings and their role in the pathogenesis of retinal branch vein occlusions. Aust NZ F Ophthalmol 1993;21:213-7. 